\title{
Bioinspired bioartifical polymer hybrid composites for propolis vaginal delivery II: formulation and characterization
}

\author{
M. Glavas-Dodov*, M. Simonoska-Crcarevska, R. Slavevska Raicki, N. Sibinovska, \\ K. Mladenovska, A. Zafirovska-Gapkovska \\ Institute of pharmaceutical technology, Faculty of pharmacy, "Ss. Cyril \& Methodius" University, Majka Teresa 47, \\ 1000 Skopje, Republic of Macedonia \\ Center of pharmaceutical nanotechnology, Faculty of pharmacy, "Ss. Cyril \& Methodius" University, Majka Teresa 47, \\ 1000 Skopje, Republic of Macedonia
}

Received: October 2014; Accepted: December 2014

\begin{abstract}
In our previous work Box-Behnken experimental design was applied for formulation optimization of the thermoreversible mucoadhesive in situ vaginal hydrogels with propolis and optimized batches were identified. Optimized batches of bioartificial polymer hybrid composites (chitosan, Lutrol@ F-127 and Lutrol@ F-68 mixture)) (CP1, CP2, CP3) were prepared using so-called cold method. Formulation P3 (chitosan free) was prepared in order to evaluate the effect of chitosan on the physico-chemical and biopharmaceutical properties of the polymer hybrid composites (gels).

The $\mathrm{pH}$ values of the gels were 4-4.5. The gelation temperature for all formulations was in a range of $29-33{ }^{\circ} \mathrm{C}$. Total flavonoids content was above $95 \%$. Increase in concentration of Lutrol ${ }^{\circledR}$ F-127 and Lutrol ${ }^{\circledR}$ F-68/Lutrol ${ }^{\circledR}$ F-127 ratio lead to a higher viscosity values and slower gel erosion/dissolution. The presence of chitosan increased gel viscosity and hence slow-down erossion/dissoluiton. Propolis release rate was the highest in $\mathrm{P} 3$ which released propolis within $5 \mathrm{~h}$, corresponding to time of complete erosion. The same correlation between erosion process and drug release rate was observed in $\mathrm{CP} 1-\mathrm{CP} 3$, where prolonged propolis release for more than $10 \mathrm{~h}$ was achieved. Microbiological quality was in accordance with the requirements of $\mathrm{Ph}$. Eur. 7 . All formulations demonstrated adequate stability at $5 \pm 3{ }^{\circ} \mathrm{C}$ during 6 months. Based on overall results it can be anticipated that bioartificial blended bioinspired polymer hybrid composites for propolis vaginal delivery could represent intelligent delivery systems with physicochemical and biopharmaceutical properties in favor or efficacious and safe therapy of vaginal infections.
\end{abstract}

Key words: thermoreversible, mucoadhesive, vaginal gels, propolis, physicochemical and biopharmaceutical characterization

\section{Introduction}

Propolis (bee glue) exhibits well-known and documented biological and pharmacological properties as antimicrobial and antifungal and most of them antiviral agent.

\footnotetext{
* tel.: +38923126032; fax: +38923123054.

e-mail:magl@ff.ukim.edu.mk
}

In this context, it is believed that most of the pharmacological effects of this composite biocomplex are due to its flavonoid content, even though the other components also contribute to its biological activity (Casaroto and Lara, 2010; Ramos and Miranda, 2007). A large number of investigations has confirmed the antifungal properties of propolis, especially its prominent activity against Can- 
dida albicans (Fearnley, 2001; Khalil, 2006; Kujumgiev et al., 1999; Marcucci, 1995; Sawaya et al., 2002), as well as its clinical efficacy in the treatment of vaginal infections. It is thought that propolis has local anesthetic and immunostimulatory effects which are also important in the treatment of vaginal infections (Pochinkova, 1995).

The gels as vaginal drug delivery systems are most commonly used dosage forms amongst the patients, due to their advantages such as easy administration and uniform spreading over the surface, allowing more intimate contact with the vaginal mucosa, precise dosing and the absence of discomfort after their administration (Das Neves and Bahia, 2006; Neves et al., 2009). However, despite these advantages, conventional gels demonstrate relatively fast drug release due to their dilution with vaginal fluids and dissolution. Another disadvantage is the possibility of liquefaction at room temperature; therefore they can leak out of the vagina. To avoid these problems, there is a need for formulation of vaginal gels with local antimicrobial activity which can provide uniform distribution over the surface of the vaginal mucosa, along with prolonged residence time and controlled drug release.

In the recent years, thermosensitive in situ-forming gel systems have been receiving a great deal of interest as vaginal delivery systems for efficient local treatment of various diseases. These environmentally sensitive systems can be easily administered due to their liquid state at room temperature, whereas their gelification in response to environmental changes offers significant advantages such as precise dosing, in vitro and in vivo stability and slow clearance from local sites due to mucoadhesive properties of the polymers used, therefore allowing prolonged drug release.

Poloxamers are poly(ethylene oxide)-poly(propylene oxide)-poly(ethylene oxide) copolymers (PEO-PPO-PEO), known under the trade name of Lutrol ${ }^{\circ}$, which form micelles at low concentration and clear thermoreversible gels at high concentrations (Alexandridis and Hatton, 1995). Poloxamers differ in their physical and surface properties due to the differences in the chemical structure. Lutrol ${ }^{\circledR}$ F-127 (LF-127) is a hydrophilic PEO-PPO-PEO tri-block copolymer (Escobar-Chávez et al., 2006) which has low toxicity, good dissolving capacity and it considered as a good vehicle for numerous active substances (Kolsure and Rajkapoor, 2012). Because of its thermoreversible gelification properties and low toxicity, LF-127 can be applied in various drug delivery systems. Lutrol@ F-68 (LF-68) contains $81 \%$ of PEO units in its composition, which makes this poloxamer easily soluble in water (Fussneger, 1999). At higher concentrations, the water solutions of LF-68 exhibit non-Newtonian behavior and thermosensitivity when the concentration exceeds 20\%. However, LF-68 is not used alone as gel-forming agent. Usually, it is combined with LF-127 in order to modify the thermorheological properties of the gels. The addition of LF-68 leads to an increase in the gelaton temperature $(T g)$, most probably due to the formation of mixed micelles and offers the advan- tage of adjusting the $\mathrm{Tg}$ value to the desired one, by varying the amount of LF-68 up to 20\%. (Fussneger, 1999). Notwithstanding the wide application of thermosensitive poloxamer gels in formulation of different drug delivery systems, their main drawback is the fast erosion due to the low mechanical strength. Therefore, prolonged retention time and controlled drug release from poloxamer gels can be achieved by the combination with other polymers, such as chitosan (CTS). The addition of CTS causes the formation of more dense poloxamer network, therefore resulting in increased mechanical strength of the gel matrix, as well as influencing the drug diffusion and slowing its release (Gratieri et al., 2010; Varshosaz et al., 2008).

As it was already rationalized (Simonoska Crcarevska et al., 2013b) by bioartificial blending bioinspired polymer hybrid composites for propolis vaginal delivery could represent intelligent delivery systems with physico-chemical and biopharmaceutical properties in favor or efficacious and safe therapy of vaginal infections. In our previous work, response surface, Box-Behnken, experimental design was applied for formulation optimization of the thermoreversible mucoadhesive in situ vaginal hydrogels with propolis and optimized batches were identified (Simonoska Crcarevska et al., 2013b). The main objective of this work was to characterize and evaluate physicochemical and biopharmaceutical properties of previously identified formulations.

\section{Materials and methods}

\section{Materials}

Chitosan (CTS, low viscous, 95\% deacetylation) was supplied from Sigma-Aldrich, USA. Poloxamers (Lutrol ${ }^{\circledR}$ F-127 and Lutrol ${ }^{\circledR}$ F-68) were obtained from BASF, Ludwigshaften, Germany. 20\% propylene-glycolic extract of propolis (PGEP) was kindly donated from Galafarm, Macedonia. All other reagents and solvents were of analytical grade and used as received.

\section{Methods}

\section{Preparation of polymer hybrid composites}

Optimized batches of bioartificial polymer hybrid composites (CTS, LF-127 and LF-68 mixture)) (thermo reversible mucoadhesive in situ gels) (CP1, CP2, CP3) were prepared according to the previously described procedure using so-called cold method with minor modification (Simonoska Crcarevska et al., 2013b). Detailed composition of the formulations is presented in Table 1.

Formulation P3 was prepared in order to evaluate the effect of CTS on the physicochemical and biopharmaceutical properties of the polymer hybrid composites (gels). 
Table 1. Composition of designed polymer hybrid composites (thermo reversible mucoadhesive in situ gels)

\begin{tabular}{lcccc}
\hline \hline $\begin{array}{l}\text { Formulation } \\
\text { code }\end{array}$ & $\begin{array}{c}\text { CTS } \\
(\%)\end{array}$ & $\begin{array}{c}\text { LF-127 } \\
(\%)\end{array}$ & $\begin{array}{c}\text { LF-68/LF-127 } \\
\text { mass ratio }\end{array}$ & $\begin{array}{c}\text { PGEP } \\
(\%)\end{array}$ \\
\hline CP1 & 1.5 & 16.39 & 0.06 & 3.0 \\
CP2 & 1.5 & 17.36 & 0.09 & 3.0 \\
CP3 & 1.5 & 18.24 & 0.12 & 3.0 \\
P3 & $/$ & 18.24 & 0.12 & 3.0 \\
\hline
\end{tabular}

\section{Preparation of simulated vaginal fluid (SVF)}

Human vaginal fluid comes from several sources such as uterus, cervix and sometimes menstrual secretions and sperm. Due to the limited quantity of human vaginal fluid (approximately $0.5-0.75 \mathrm{~mL}$ ) and its rapid degradation after collection from its source, a simulated vaginal fluid (SVF) was developed (Aka-Any-Grah et al., 2010). SVF was prepared as follows: $\mathrm{NaCl}(3.51 \mathrm{~g}), \mathrm{KOH}(1.4 \mathrm{~g})$, $\mathrm{Ca}(\mathrm{OH})_{2}(0.22 \mathrm{~g})$, bovine serum albumin $(0.018 \mathrm{~g})$, lactic acid $(2.00 \mathrm{~g})$, acetic acid (1.00 g), glycerol (0.16 g), urea $(0.4 \mathrm{~g})$ and glucose $(5.00 \mathrm{~g})$ were added to $900 \mathrm{ml}$ distilled water and stirred mechanically until complete dissolution. The $\mathrm{pH}$ of the SVF was then adjusted to 4.5 using $0.1 \mathrm{M}$ $\mathrm{HCl}$, and the final volume was adjusted to $1 \mathrm{~L}$.

\section{Characterization of polymer hybrid composites (thermo- reversible mucoadhesive in situ gels)}

\section{Visual characterization}

Visual characterization of color, appearance, odor, texture and phase separation on designed and prepared formulations were carried out.

\section{pH determination}

Adequacy of designed polymer hybrid composites (thermo reversible mucoadhesive in situ gels) for vaginal use were evaluated by determination of their $\mathrm{pH}$ value $(\mathrm{pH}$ meter, Metler Toledo 340, Germany). $\mathrm{pH}$ evaluation was carried out in triplicate.

\section{Determination of of the sol-gel transition temperature}

The sol-gel transition temperature $(\mathrm{Tg})$ of the designed formulations was measured by tube inversion method (UrRehman et al., 2010) with minor modifications (Simonoska Crcarevska et al., 2013b). Briefly, $2 \mathrm{ml}$ of prepared formulations were transferred into a glass test tube sealed with a parafilm and put in horizontal shaker water bath (50 strokes/ $\mathrm{min}$ ). The temperature of the water bath was gradually increased $\left(1{ }^{\circ} \mathrm{C} / \mathrm{min}\right)$ and the temperature at which the solution in the sample containing tube stopped flowing upon inverting the tube was recorded. Similarly, the temperature was decreased and the temperature, at which the gel started flowing, was recorded. The average of both temperatures was calculated as the critical $T g$.

Considering the possibility of change in the $T g$ of the formulations after their dilution with vaginal fluid (AkaAny-Grah et al., 2010), the $T g$ of each formulation was also investigated after the addition of $0.75 \mu \mathrm{l}$ of SVF.

\section{Determination of propolis content}

Propolis content in the prepared formulations was determined by validated spectrophotometric method (395 nm, Lambda 16, Perkin Elmer, USA) where quantification of the total flavonoid content was done using chrysin as external reference standard. Briefly, $1 \mathrm{~g}$ of prepared formulations was dissolved in $100 \mathrm{ml}$ methanolic solution of acetic acid $(0.5 \% \mathrm{v} / \mathrm{v}) .2 \mathrm{ml}$ of prepared solution and exactly $1 \mathrm{ml}$ of aluminum chloride water solution $(2 \% \mathrm{w} / \mathrm{w})$ were transferred in glass volumetric flask and methanolic solution of acetic acid $(0.5 \%, \mathrm{v} / \mathrm{v})$ was added to a total volume of $10 \mathrm{ml}$. In parallel a compensatory solution was prepared on the same way without aluminum chloride. In the same manner external reference standard of chrysin was prepared $(0.02 \% \mathrm{w} / \mathrm{v})$. Three replicates were carried out to estimate the inherent variability of the determination and the total flavonoids content was expressed in mg of chrysin equivalents per gram of prepared formulations.

\section{Viscosity determination}

The viscosity $\left(\mathrm{mPa}^{*} \mathrm{~s}\right)$ of the prepared polymer hybrid composites (thermo-reversible mucoadhesive in situ gels) was determined using cone/plate viscometer (Myr V2-L, 4.6/MOTv2, Viscotech, Spain). A sample solution (0.5 ml) was applied to the lower plate of the viscometer and viscosity was determined at at $25 \pm 0.5^{\circ} \mathrm{C}$ and $32 \pm 0.5^{\circ} \mathrm{C}$ using spindle 52 at a shear rate ranging from 5 to $400 \mathrm{rpm}$. All samples were analyzed in triplicate.

Erosion/dissolution and in vitro propolis release studies

Thermo-reversible mucoadhesive in situ gels erosion/ dissolution profile and the in vitro propolis release from the designed formulations were obtained simultaneously. Briefly, $2 \mathrm{~g}$ of each formulation were transferred in glass tubes, weighted and placed in horizontal shaker water bath (40 rpm) previously thermostated at $32{ }^{\circ} \mathrm{C}$. After the gelation, $10 \mathrm{ml}$ of SVF pre-equilibrated at $32{ }^{\circ} \mathrm{C}$ were added. At pre-determined time intervals $(1,2,3,4,5,6,7,8$ and $12 \mathrm{~h}$ ) the total volume of liquid medium was removed, and the weight of eroded/dissolved gel was calculated from the change in the weight (glass tube with gel) at the beginning of the experiment and at each time interval.

Afterwards the release medium was completely replaced by $10 \mathrm{ml}$ of fresh medium at predetermined time intervals. The concentration of propolis in the release medium was determined spectrophotometrically as it was previously described. All experiments were performed as triplicates.

In vitro propolis release modeling and release profile comparison were performed with DDSolver 1.0 program (menu-driven add-in program for Microsoft Excel) (Simonoska Crcarevska et al., 2013a; Zhang et al., 2010). 


\section{Microbiological quality}

The microbiological quality of the prepared formulations was evaluated according to the Ph.Eur.7 method 2.6.12 (Microbiological examination of non-sterile products (total viable aerobic count)) and method 2.6.13 (test for specified microorganisms)). The acceptance criteria for microbiological quality of vaginal preparations stated in the Ph.Eur.7 (5.1.4 - Microbiological quality of non-sterile pharmaceutical preparations and substances for pharmaceutical use) are based on the total aerobic microbial count (TAMC) and total yeast and mold count (TYMC).

\section{Stability studies}

Prepared formulations were sealed in glass vials and stored under controlled conditions $\left(25 \pm 2{ }^{\circ} \mathrm{C}\right.$ and $5 \pm 3$ ${ }^{\circ} \mathrm{C}$ ). Periodical testing of different parameters (organoleptic properties, $\mathrm{pH}$ value, propolis content, microbiological quality) during 6 months was performed.

\section{Results and discussion}

In our previous work (Simonoska Crcarevska et al., 2013b) response surface Box-Benken experimental design was used for development and optimization of propolis vaginal delivery system (polymer hybrid composites (thermo-reversible mucoadhesive in situ gels)) with desired gelling properties. Key formulation factors influencing $\mathrm{Tg}$ were determined and optimization of formulation was carried out. Optimized batches with $\mathrm{Tg}$ of $32^{\circ} \mathrm{C}(\mathrm{CP} 1-$ CP3) were prepared and characterized accordingly.

\section{Characterization of polymer hybrid composites (thermo- reversible mucoadhesive in situ gels)}

The $\mathrm{pH}$ values of the prepared propolis vaginal delivery system were in the range of 4 to 4.5 pointing to suitability of formulations for vaginal use (Table 2).

The gelation temperature was determined for all prepared formulations (CP1-CP3, P3) before and after their dilution with $0.75 \mu \mathrm{L}$ SVF (Table 2).
Obtained results showed an increase of $\sim 2^{\circ} \mathrm{C}$ in $T g$ of the formulations diluted with SVF. These differences could be explained by the presence of co-solutes, i.e. ions and electrolytes in the SVF which probably interacted with poloxamers. Considering the strong relation between the gelation and micellization processes, the observed increase of $\mathrm{Tg}$ value is most likely related to the increased critical micelle concentration or critical micelle temperature. The results of our study also showed that the $\mathrm{Tg}$ of the P3 formulation prepared without chitosan was slightly higher compared to other formulations (CP1-CP3). Similar findings were reported by Gratieri et al. (Gratieri et al., 2010), indicating that CTS has an effect on the crosslinking and the packing of polymer chains, thus resulting in a denser network which gelled at lower temperature.

Total flavonoids content in the prepared formulations (CP1-CP3) was above 95\% (Table 2).

The efficacy of gels intended for local treatment of vaginal infections depends to a great extent on the rheological characteristics of the system. Namely, improved therapeutic efficacy could be achieved by prolonged residence time at the site of action (vaginal mucosa) as well as controlled drug release (propolis) from hybrid polymer matrix. Rheological characteristics are influenced by various factors such as the composition of formulations (polymers used as gel-forming agents), temperature, vaginal $\mathrm{pH}$ value, amount of vaginal fluid etc. Comparing viscosity values measured at 25 and $32{ }^{\circ} \mathrm{C}$ it can be noticed that prepared polymer hybrid composites (thermo-reversible mucoadhesive in situ gels) were characterized by higher viscosity at $32^{\circ} \mathrm{C}$ as it was expected due to thermosensitive properties of used poloxamers. Obatined results pointed that by increasing the concentrations of LF-127 and LF68/LF-127 ratio, higher viscosity values were observed. Formulation P3 was characterized by lower viscosity compared to CP1-CP3 (Table 2).

\section{Erosion/dissolution and in vitro propolis release studies}

Fig. 1 presents the effect of formulation variables (LF127 and LF-68/LF-127 ratio (CP1-CP3)), as well as CTS

Table 2. Gelation temperature $(T g)$ (mean $\pm \mathrm{SD}$ ) of the designed polymer hybrid composites (thermo reversible mucoadhesive in situ gels $)(n=3)$

\begin{tabular}{cccccccc}
\hline \hline $\begin{array}{c}\text { Formulation } \\
\text { code }\end{array}$ & $\begin{array}{c}\mathrm{pH} \text { values } \\
\pm \mathrm{SD}\end{array}$ & $\begin{array}{c}\mathrm{Tg}\left({ }^{\circ} \mathrm{C}\right) \pm \mathrm{SD} \\
\text { without } \\
\text { SVF }\end{array}$ & $\begin{array}{c}\text { with } \\
0.75 \mu \mathrm{l} \mathrm{SVF}\end{array}$ & $\mathrm{mg} / \mathrm{g} \pm \mathrm{SD}$ & $\begin{array}{c}\text { Total flavonoids } \\
\text { of the declared } \\
\text { content } \pm \mathrm{SD}\end{array}$ & $25 \pm 0.5^{\circ} \mathrm{C}$ & $37 \pm 0.5^{\circ} \mathrm{C}$ \\
\hline $\mathrm{CP} 1$ & $4.36 \pm 0.03$ & $29 \pm 0.03$ & $31 \pm 0.05$ & $2.46 \pm 0.01$ & $95.17 \pm 0.67$ & $1180 \pm 0.2$ & $65220 \pm 0.5$ \\
$\mathrm{CP} 2$ & $4.06 \pm 0.02$ & $29 \pm 0.02$ & $31 \pm 0.01$ & $2.59 \pm 0.02$ & $99.87 \pm 0.75$ & $1340 \pm 0.3$ & $167930 \pm 0.3$ \\
$\mathrm{CP} 3$ & $4.13 \pm 0.04$ & $29 \pm 0.03$ & $31 \pm 0.05$ & $2.55 \pm 0.02$ & $98.55 \pm 0.79$ & $1470 \pm 0.1$ & $219600 \pm 0.3$ \\
$\mathrm{P} 3$ & $4.50 \pm 0.05$ & $32 \pm 0.02$ & $33 \pm 0.04$ & $2.58 \pm 0.02$ & $99.15 \pm 0.74$ & $930 \pm 0.1$ & $33700 \pm 0.8$ \\
\hline
\end{tabular}


(P3 compared to CP3) on the gel erosion/dissolution vs time. Erosion/dissolution of formulation P3 (CTS free) was completed in $4.5 \mathrm{~h}$, while CP1-CP3 showed decrease in the rate of gel erosion, 5.5-8.5 $\mathrm{h}$ accordingly. Results obtained for P3 (CTS free) were in accordance with the literature data, which suggest that gels consisted only by poloxamers dissociate rapidly in an aqueous environment (Chung et al., 2009). The observed results for CP1-CP3 pointed that increase in concentration of LF-127 and LF-68/LF-127 ratio lead to a higher viscosity of the system, thereby causing the formation of more dense gel network which erodes at a slower rate. The presence of CTS retarded the gel erosion/ dissolution due to its incorporation into the gel skeleton most likely resulting with increased mechanical strength of the gel network (Varshosaz et al., 2008).

The results of in vitro propolis release study are presented in Fig. 2. It can be seen that propolis release follows gel erosion/dissolution processes. Propolis release rate was the highest in P3 formulation (CTS free), which released propolis within $5 \mathrm{~h}$, corresponding to time of complete erosion. Furthermore, the same correlation between erosion process and drug release rate was observed in formulations $\mathrm{CP} 1-\mathrm{CP} 3$, where prolonged propolis release for more than $10 \mathrm{~h}$ was achieved, due to the effect of CTS.

The continuous swelling of poloxamers accounts for achieving prolonged drug release when used as gelling agents. Additionally, drug diffusion occurs through the extramicellar aqueous channels formed during matrix erosion/dissolution. Hence, the decrease in the rate of propolis release with the increase in LF-127 concentration could be attributed to the increase of number and size of the micelles formed at higher polymer concentration (Radivojša et al., 2013). This could cause a greater extent of polymer chains entanglement in the aqueous phase of the gel structure and slower dissolution rate. Additionally, higher poloxamer concentration could cause shorter intermicellar distance, leading to a larger number of cross-links between neighboring micelles and larger number of micelles per volume, along with subsequently slower rate of dissolution of the incorporated drug (Ibrahim et al., 2012).

Even though the chosen polymers differ in terms of chemical structure, both CTS and poloxamers have hydrophobic regions in their chains (D-glucose residues in chitosan and polypropyloxyethylene blocks in poloxamers). When the temperature is increased, water molecules structured around the hydrophobic regions of polymer chains in a sol state become disarranged. As a result, newly revealed hydrophobic regions attract each other to form bonds, whereas hydrophilic parts reorganize to maximize their contact with the aqueous medium. The resulting structures are micelles, which continue to grow in size and number at higher temperatures, leading to higher viscosity of the gel structure and consequently, slower rate of drug release is achieved (Varshosaz et al., 2008).

Drug release kinetics of propolis from the prepared formulations was determined by analyzing the dissolution data using various mathematical models. The kinetics constants and correlation coefficients for propolis release are shown in Table 3. Taking into account the values of correlation coefficients (R), it can be concluded that Korsmeyer-Peppas model is the best one to describe the propolis release from the prepared formulations. According to the obtained values of release rate constant $(\mathrm{K})$, it can be claimed that the drug dissolution rate decreases with the increase of LF-127 and LF68 concentrations, as expected. Predominance of diffusion in release mechanisam was observed for CP1-CP3, while P3 (without CTS) demonstrated release mechanism most likely controlled by diffusion and gel erosion/dissolution.

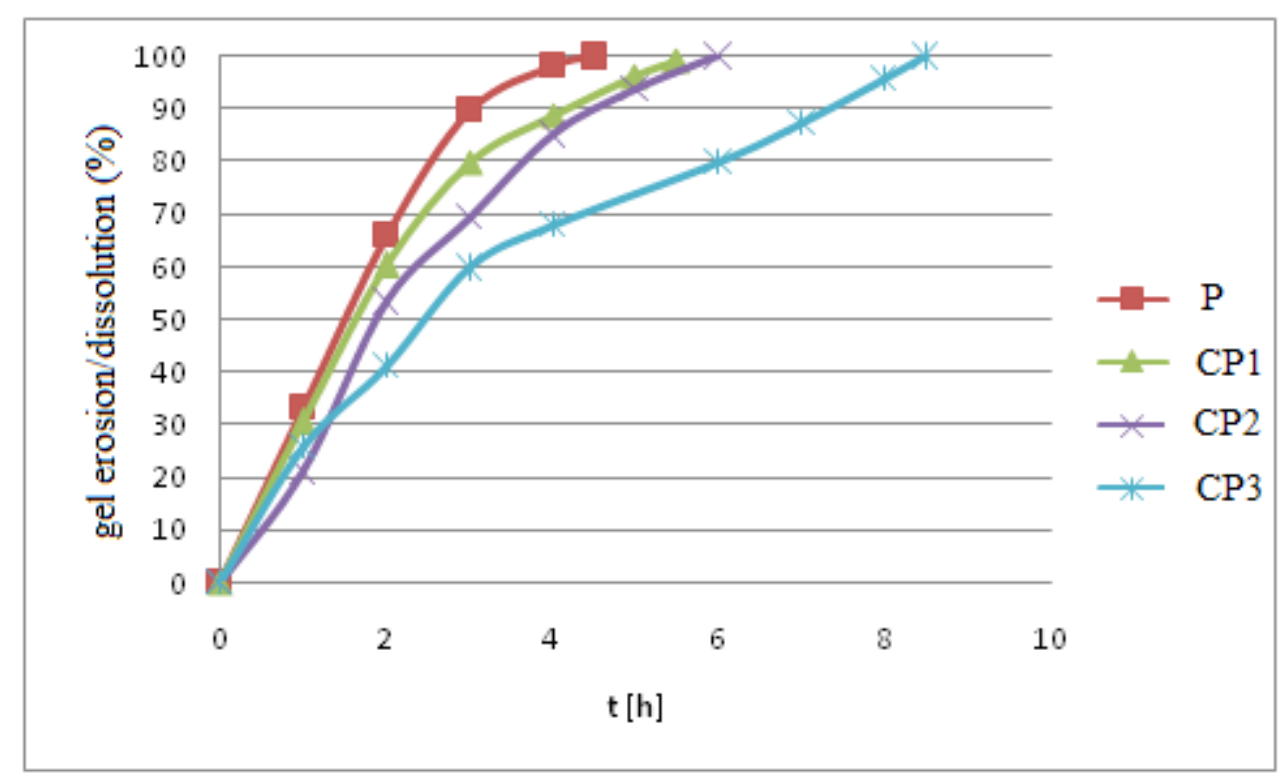

Fig. 1. Gel erosion/dissolution of designed polymer hybrid composites (thermo reversible mucoadhesive in situ gels). 


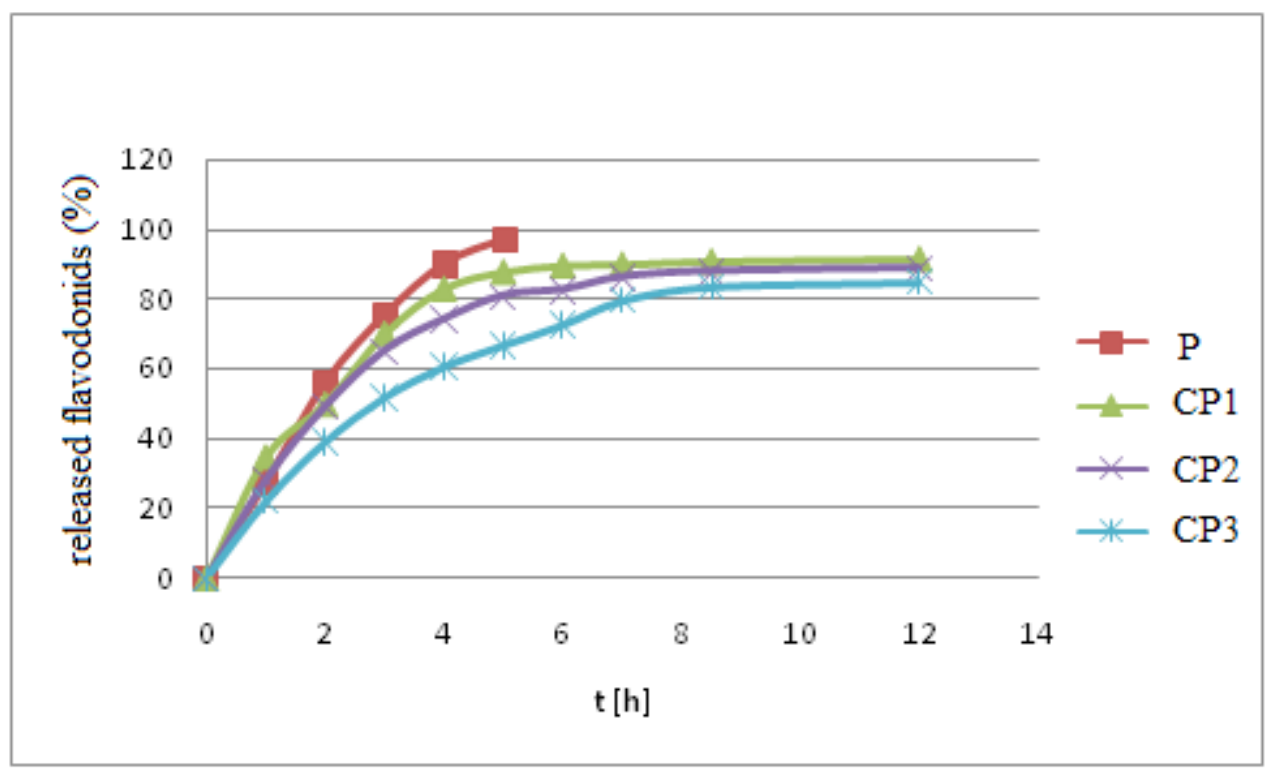

Fig. 2. In vitro release profiles of propolis from designed polymer hybrid composites (thermo reversible mucoadhesive in situ gels).

Table 3. Kinetics constants and coefficients for propolis release from the prepared formulations

\begin{tabular}{ccccccccccc}
\hline \hline $\begin{array}{c}\text { Formulation } \\
\text { code }\end{array}$ & \multicolumn{2}{c}{ First order } & \multicolumn{2}{c}{ Higuchi } & \multicolumn{3}{c}{ Korsmeyer-Peppas } & \multicolumn{3}{c}{ Peppas-Sahlin } \\
& $\mathrm{K}(1 / \mathrm{h})$ & $\mathrm{R}$ & $\mathrm{K}\left(\mathrm{h}^{-0.5}\right)$ & $\mathrm{R}$ & $\mathrm{n}$ & $\mathrm{K}\left(\mathrm{h}^{-\mathrm{n}}\right)$ & $\mathrm{R}$ & $\mathrm{k} 1$ & $\mathrm{k} 2$ & $\mathrm{R}$ \\
\hline $\mathrm{CP} 1$ & 0.356 & 0.9890 & 33.475 & 0.9232 & 0.565 & 35.165 & 0.9913 & 51.756 & -6.939 & 0.9807 \\
$\mathrm{CP} 2$ & 0.367 & 0.9831 & 31.638 & 0.9456 & 0.613 & 30.445 & 0.9888 & 45.993 & -5.449 & 0.9833 \\
$\mathrm{CP} 3$ & 0.194 & 0.9811 & 28.019 & 0.9800 & 0.542 & 27.545 & 0.9951 & 33.266 & -1.991 & 0.9856 \\
P3 & 0.446 & 0.9869 & 42.264 & 0.9809 & 0.793 & 29.625 & 0.9906 & 25.012 & 9.175 & 0.9927 \\
\hline
\end{tabular}

\section{Microbiological quality}

The obtained results related to microbiological quality were in accordance with the requirements stated in Ph.Eur. 7.

\section{Stability studies}

The results of the stability studies of the prepared formulations stored at $25 \pm 2{ }^{\circ} \mathrm{C}$ and $5 \pm 3{ }^{\circ} \mathrm{C}$ during 6 months are presented in Table 4 and 5, respectively.

Formulations $\mathrm{CP} 1$ and $\mathrm{CP} 2$ demonstrated adequate stability during 6 months of storage at $25 \pm 2{ }^{\circ} \mathrm{C}$ without any significant changes in their organoleptic properties, $\mathrm{pH}$ values, propolis content, viscosity and microbiological quality. CP3 formulation showed adequate stability during 5 months of storage $25 \pm 2{ }^{\circ} \mathrm{C}$, but after 6 months changes in its organoleptic properties were observed, i.e. viscous liquid was formed. On the other hand, all formulations demonstrated adequate stability at $5 \pm 3{ }^{\circ} \mathrm{C}$ during 6 months.

\section{Conclusion}

To summarize in this work by bioartifical blending of natural and synthetic polymers thermo reversible mucoadhesive in situ gels were prepared and characterized. Addition of bio/mucoadhesive macromolecules (chitosan) to the poloxamers (Lutrol ${ }^{\circledR}$ F-127 and Lutrol ${ }^{\circledR}$ F-68) based vaginal delivery system resulted with increased viscosity, decreased gel erosion/dissolution rate thus improving the sustained release of propolis. Chitosan not only helped to circumvent draw backs of poloxamer gels alone like fast erosion/ dissolution, but also did not adversely affect its thermosensitive behavior. Based on the results obtained it can be concluded that chitosan-poloxamer based systems would enable prolonged residence time allowing prolonged drug release at the desired site of action and hence resulting with better therapeutic efficacy. 
Table 4. Results from stability studies of the prepared formulations stored at $25 \pm 2{ }^{\circ} \mathrm{C}$ during 6 months period

\begin{tabular}{|c|c|c|c|c|c|c|c|c|}
\hline \multirow{2}{*}{ Parameter } & \multirow{2}{*}{$\begin{array}{l}\text { Formula- } \\
\text { tion code }\end{array}$} & \multicolumn{7}{|c|}{ Time of evaluation (month) } \\
\hline & & 0 & 1 & 2 & 3 & 4 & 5 & 6 \\
\hline \multirow{3}{*}{ Organoleptic properties } & $\mathrm{CP} 1$ & \\
\hline & CP2 & \multicolumn{7}{|c|}{ Dense homogenous liquid with yellow-brownish color and propolis smell } \\
\hline & $\mathrm{CP} 3$ & \multicolumn{6}{|c|}{ Dense homogenous liquid with yellow-brownish color and propolis smell } & $\begin{array}{l}\text { liquid with a yellow- } \\
\text { brownish color and } \\
\text { propolis smell }\end{array}$ \\
\hline \multirow{4}{*}{$\mathrm{pH}$ value } & $\mathrm{CP} 1$ & $4.36 \pm 0.2$ & $4.25 \pm 0.15$ & $4.31 \pm 0.1$ & $4.2 \pm 0.13$ & $4.22 \pm 0.08$ & $4.18 \pm 0.1$ & $4.09 \pm 0.11$ \\
\hline & $\mathrm{CP} 2$ & $4.06 \pm 0.1$ & $3.97 \pm 0.12$ & $4.00 \pm 0.13$ & $3.95 \pm 0.09$ & $3.91 \pm 0.1$ & $3.85 \pm 0.08$ & $3.79 \pm 0.1$ \\
\hline & $\mathrm{CP} 3$ & $4.13 \pm 0.14$ & $4.00 \pm 0.11$ & $4.09 \pm 0.1$ & $3.98 \pm 0.12$ & $3.94 \pm 0.07$ & $3.93 \pm 0.1$ & $4.1 \pm 0.13$ \\
\hline & $\mathrm{CP} 1$ & $95.17 \pm 1.1$ & $94.83 \pm 0.9$ & $98.99 \pm 1.07$ & $95.98 \pm 1.5$ & $95.64 \pm 1.34$ & $95.98 \pm 1.46$ & $94.52 \pm 0.94$ \\
\hline \multirow[t]{3}{*}{$\begin{array}{l}\text { Total flavonoid } \\
\text { (\% of declared content) }\end{array}$} & $\mathrm{CP} 2$ & $99.87 \pm 1.5$ & $99.88 \pm 1.84$ & $103.63 \pm 0.6$ & $101.35 \pm 1.2$ & $99.65 \pm 1.74$ & $99.77 \pm 1.36$ & $102.56 \pm 0.8$ \\
\hline & $\mathrm{CP} 3$ & $98.55 \pm 1.3$ & $98.3 \pm 0.5$ & $106.99 \pm 2.3$ & $103.78 \pm 1.82$ & $97.14 \pm 1.12$ & $94.17 \pm 1.9$ & $98.19 \pm 0.96$ \\
\hline & $\mathrm{CP} 1$ & $1180 \pm 0.2$ & l & / & l & l & I & $1190 \pm 0.4$ \\
\hline \multirow[t]{3}{*}{ Viscosity $\left(\mathrm{mPa}^{*} \mathrm{~s}\right)$} & $\mathrm{CP} 2$ & $1340 \pm 0.3$ & l & l & l & l & / & $1380 \pm 0.9$ \\
\hline & $\mathrm{CP} 3$ & $1470 \pm 0.1$ & I & / & l & l & / & / \\
\hline & $\mathrm{CP} 1$ & Yes & / & l & I & I & / & Yes \\
\hline \multirow[t]{2}{*}{$\begin{array}{l}\text { Microbiological quality criteria } \\
\text { compliance }\end{array}$} & $\mathrm{CP} 2$ & Yes & I & I & I & I & ' & Yes \\
\hline & $\mathrm{CP} 3$ & Yes & / & / & / & l & l & Yes \\
\hline
\end{tabular}

Table 5. Results from stability studies of the prepared formulations stored at $5 \pm 3{ }^{\circ} \mathrm{C}$ during 6 months period

\begin{tabular}{|c|c|c|c|c|c|c|c|c|}
\hline \multirow{2}{*}{ Parameter } & \multirow{2}{*}{$\begin{array}{l}\text { Formula- } \\
\text { tion code }\end{array}$} & \multicolumn{7}{|c|}{ Time of evaluation (month) } \\
\hline & & 0 & 1 & 2 & 3 & 4 & 5 & 6 \\
\hline \multirow{3}{*}{ Organoleptic properties } & $\mathrm{CP} 1$ & \multirow{2}{*}{\multicolumn{5}{|c|}{ Dense homogenous liquid with yellow-brownish color and propolis smell }} & & \\
\hline & $\mathrm{CP} 2$ & & & & & & & \\
\hline & $\mathrm{CP} 3$ & & & & & & & \\
\hline \multirow{3}{*}{$\mathrm{pH}$ value } & $\mathrm{CP} 1$ & $4.36 \pm 0.2$ & $4.02 \pm 0.1$ & $3.99 \pm 0.14$ & $3.97 \pm 0.1$ & $3.82 \pm 0.3$ & $3.90 \pm 0.16$ & $3.78 \pm 0.2$ \\
\hline & $\mathrm{CP} 2$ & $4.06 \pm 0.1$ & $4.30 \pm 0.9$ & $4.25 \pm 0.5$ & $4.20 \pm 0.4$ & $4.19 \pm 0.1$ & $4.23 \pm 0.09$ & $4.09 \pm 0.18$ \\
\hline & $\mathrm{CP} 3$ & $4.13 \pm 0.14$ & $4.09 \pm 0.56$ & $4.01 \pm 0.28$ & $3.98 \pm 0.35$ & $3.95 \pm 0.2$ & $3.97 \pm 0.25$ & $3.86 \pm 0.3$ \\
\hline \multirow{3}{*}{$\begin{array}{l}\text { Total flavonoid } \\
\text { ( } \% \text { of declared content) }\end{array}$} & $\mathrm{CP} 1$ & $95.17 \pm 1.1$ & $98.84 \pm 0.7$ & $96.52 \pm 1.22$ & $94.98 \pm 2.31$ & $94.21 \pm 0.8$ & $96.14 \pm 1.98$ & $95.75 \pm 2.21$ \\
\hline & $\mathrm{CP} 2$ & $99.87 \pm 1.5$ & $103.08 \pm 1.82$ & $99.61 \pm 1.93$ & $99.23 \pm 1.85$ & $98.84 \pm 1.32$ & $101.54 \pm 2.23$ & $102.38 \pm 1.3$ \\
\hline & $\mathrm{CP} 3$ & $98.55 \pm 1.3$ & $107.72 \pm 1.31$ & $94.21 \pm 2.15$ & $98.84 \pm 1.96$ & $92.28 \pm 1.64$ & $103.47 \pm 1.57$ & $98.07 \pm 1.84$ \\
\hline \multirow{3}{*}{ Viscosity $\left(\mathrm{mPa}^{*} \mathrm{~s}\right)$} & $\mathrm{CP} 1$ & $1180 \pm 0.2$ & $1180 \pm 0.8$ & I & l & I & I & $1190 \pm 0.4$ \\
\hline & $\mathrm{CP} 2$ & $1340 \pm 0.3$ & $1340 \pm 0.7$ & / & I & / & / & $1380 \pm 0.9$ \\
\hline & $\mathrm{CP} 3$ & $1470 \pm 0.1$ & $1470 \pm 0.5$ & l & I & I & I & $1560 \pm 0.8$ \\
\hline \multirow{3}{*}{$\begin{array}{l}\text { Microbiological quality criteria } \\
\text { compliance }\end{array}$} & $\mathrm{CP} 1$ & Yes & Yes & / & l & I & I & Yes \\
\hline & $\mathrm{CP} 2$ & Yes & Yes & I & I & 1 & I & Yes \\
\hline & $\mathrm{CP} 3$ & Yes & Yes & / & l & / & / & Yes \\
\hline
\end{tabular}




\section{Reference}

Aka-Any-Grah, A., Bouchemal, K., Koffi, A., Agnely, F., Zhang, M., Djabourov, M., Ponchel, G., 2010. Formulation of mucoadhesive vaginal hydrogels insensitive to dilution with vaginal fluids. Eur. J. Pharm. Bipharm. 76, 296-303.

Alexandridis, P., Hatton, T.A., 1995. Poly (ethylene oxide) - poly (propylene oxide) - poly (ethylene oxide) block copolymer surfactants in aqueous solutions and at interfaces: thermodynamics, structure, dynamics, and modeling. Colloid. Surface. A 96, 1-46.

Casaroto, A.R., Lara, V.S., 2010. Phytomedicines for Candidaassociated denture stomatitis. Fitoterapia 81, 323-328.

Chung, T.-W., Lin, S.-Y., Liu, D.-Z., Tyan, Y.-C., Yang, J.S., 2009. Sustained release of 5-FU from Poloxamer gels interpenetrated by crosslinking chitosan network. Int. J. Pharm. 382, 39-44.

Das Neves, J., Bahia, M., 2006. Gels as vaginal drug delivery systems. Int. J. Pharm. 318, 1-14.

Escobar-Chávez, J., López-Cervantes, M., Naik, A., Kalia, Y., Quintanar-Guerrero, D., Ganem-Quintanar, A., 2006. Applications of thermo-reversible pluronic F-127 gels in pharmaceutical formulations. J. Pharm. Pharm. Sci. 9, 339-358.

Fearnley, J., 2001. Bee Propolis: Natural Healing from the Hive, Souvenir Press.

Fussneger, B., 1999. Poloxamers (1) Lutrol ${ }^{\circledR}$ F 68 (Poloxamer 188) BASF product info. BASF ExAct (1999-11-03), pp. 5-6.

Gratieri, T., Gelfuso, G.M., Rocha, E.M., Sarmento, V.H., de Freitas, O., Lopez, R.F.V., 2010. A poloxamer/chitosan in situ forming gel with prolonged retention time for ocular delivery. Eur. J. Pharm. Biopharm. 75, 186-193.

Ibrahim, E.-S., Ismail, S., Fetih, G., Shaaban, O., Hassanein, K., Abdellah, N., 2012. Development and characterization of thermosensitive pluronic-based metronidazole in situ gelling formulations for vaginal application. Acta pharmaceut. 62, 59-70.

Khalil, M.L., 2006. Biological activity of bee propolis in health and disease. Asian Pac. J. Cancer Prev. 7, 22-31.

Kolsure, P.K., Rajkapoor, B., 2012. Development of zolmitriptan gel for nasal administration. Asian J. Pharm. and Clin. Res $5,88-94$.

Kujumgiev, A., Tsvetkova, I., Serkedjieva, Y., Bankova, V., Christov, R., Popov, S., 1999. Antibacterial, antifungal and antiviral activity of propolis of different geographic origin. J. Ethnopharmacol. 64, 235-240.

Marcucci, M.C., 1995. Propolis: chemical composition, biological properties and therapeutic activity. Apidologie 26, 83-99.

Neves, J.d., da Silva, M.V., Gonçalves, M.P., Amaral, M.H., Bahia, M.F., 2009. Rheological properties of vaginal hydrophilic polymer gels. Curr. Drug Deliv. 6, 83-92.

Pochinkova, P., 1995. Bee Products in Medicine-apitherapy, 2nd ed. "Prof. Marin Drinov" Academic Publishing House, Sofia.

Radivojša, M., Grabnar, I., Grabnar, P.A., 2013. Thermoreversible in situ gelling poloxamer-based systems with chitosan nanocomplexes for prolonged subcutaneous delivery of heparin: Design and in vitro evaluation. Eur. J. Pharm. Sci. 50, 93-101.

Ramos, A., Miranda, J., 2007. Propolis: a review of its antiinflammatory and healing actions. JVATiTD 13, 697-710.

Sawaya, A., Palma, A., Caetano, F., Marcucci, M., da Silva Cunha, I., Araujo, C., Shimizu, M., 2002. Comparative study of in vitro methods used to analyse the activity of propolis extracts with different compositions against species of Candida. Lett. Appl. Microbiol. 35, 203-207.

Simonoska Crcarevska, M., Geskovski, N., Calis, S., Dimchevska, S., Kuzmanovska, S., Petruševski, G., Kajdžanoska, M., Ugarkovic, S., Goracinova, K., 2013a. Definition of formulation design space, in vitro bioactivity and in vivo biodistribution for hydrophilic drug loaded PLGA/PEOPPO-PEO nanoparticles using OFAT experiments. Eur. J. Pharm. Sci. 49, 65-80.

Simonoska Crcarevska, M., Zafirovska Gapkovska, A., Mladenovska, K., Raicki, R.S., Geskovski, N., Dimcevska, S., Glavas Dodov, M., 2013b. Bioinspired bioartifical polymer hybrid composites for propolis vaginal delivery I: formulation development and optimization of gelling temperature using experimental design. Maced. Pharm. Bull. $59,33-40$.

Ur-Rehman, T., Tavelin, S., Gröbner, G., 2010. Effect of DMSO on micellization, gelation and drug release profile of Poloxamer 407. Int. J. Pharm. 394, 92-98.

Varshosaz, J., Tabbakhian, M., Salmani, Z., 2008. Designing of a Thermosensitive Chitosan/Poloxamer In Situ Gel for Ocular Delivery of Ciprofloxacin. TODDJ 2, 61-70.

Zhang, Y., Huo, M., Zhou, J., Zou, A., Li, W., Yao, C., Xie, S., 2010. DDSolver: an add-in program for modeling and comparison of drug dissolution profiles. The AAPS journal $12,263-271$ 


\title{
Резиме
}

\section{Биоинспирирани биовештачки полимерни хибридни композити со контролирано ослободување на прополис во вагина II: формулација и карактеризација}

\author{
Марија Главаш-Додов, Маја Симоноска-Црцаревска, Рената Славеска-Раички, \\ Надица Сибиновска, Кристина Младеновска, Ана Зафировска-Гапковска
}

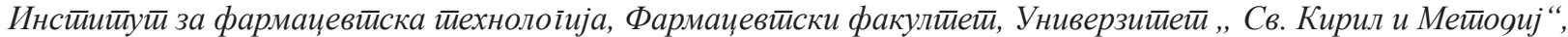 \\ Мајка Тереза 47, 1000 Скойје, Рейублика Макеоонија

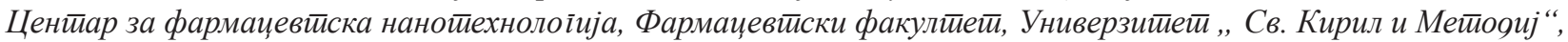 \\ Мајка Тереза 47, 1000 Скойје, Рейублика Макеоонија
}

Клучни зборови: термореверзибилни, мукоатхезивн, вагинални гели, прополис, физичко-хемиска и биофармацевтска карактеризација

Во нашиот претходен труд со примена на Box-Behnken експериментален дизајн беше направена оптимизација на термореверзибилни мукоатхезивни in situ вагинални хидрогели со прополис. Оптимизираните формулации на биовештачки полимерни хибридни композити (смеса на цитозан, Lutrol® F-127 и Lutrol® F-68) (CP1, CP2, CP3) беа подготвени со примена на т.н. ладен метод. Формулацијата Р3 која не содржи цитозан, беше подготвена со цел да се евалуира влијанието на цитозанот врз физичко-хемиските и биофармацевтските особини на полимерните хибридни композити (гели). Подготвените гели се карактеризираа со рН од 4-4,5. Температурата на гелирање кај сите формулации беше во опсег од 29-33 ${ }^{\circ} \mathrm{C}$. Содржината на вкупните флавоноиди беше поголема од 95\%. Зголемувањето на концентрацијата на Lutrol® F-127 и односот на Lutrol® F-68/Lutrol® F-127 резултираше со поголеми вредности на вискозитетот и побавна ерозија/дисолуција на гелите. Присуството на цитозанот во формулацијата резултираше со зголемување на вискозитетот на гелот и негова побавна ерозија/дисолуција. Брзината на ослободување на прополисот беше најголема кај формулацијата Р3 кај која целата количина на прополис беше ослободена за 5 часа, што кореспондираше со времето на комплетна ерозија на гелот. Слична корелација меѓу процесот на ерозија и брзината на ослободување на прополисот беше забележана и кај формулациите СР1-СР3, кај кои беше постигнато продолжено ослободување на прополисот во период поголем од 10 часа. Микробиолошкиот квалитет на подготвените формулации беше во согласност со барањата на Ph. Eur. 7. Сите формулации беа стабилни на $5 \pm 3{ }^{\circ} \mathrm{C}$ во тек на 6 месеци. Врз база на севкупните резултати може да се заклучи дека биовештачките блендирани биоинспирарни полимерни хибридни композити со контролирано ослободување на прополис може да преставуваат интелегентни вагинални системи со физичко-хемиски и биофармацевтски особини кои ќе овозможат ефикасен и безбеден третман на вагиналните инфекции. 
